\title{
THE IMPACT OF INCOME AND PLACE OF LIVING ON HEALTH BEHAVIORS IN A RANGE OF ORAL HYGIENE ON THE BASIS OF THE SURVEYED PATIENTS
}

\begin{abstract}
Summary
The aim of research was to determine patients' health behaviors in the range of oral hygiene regarding their income and place of living. Study included 180 patients, 90 women and 90 men, aged 35-44 from a big city, smaller cities and villages of West Pomerania region. Dental examination was performed, which allowed to evaluate oral health state. Questionnaire including utilization of dental services, oral hygiene and access to dental services was completed by patients. Vast majority of women and men brush their teeth twice a day, however women more often than men brush their teeth after every meal. Regardless of the place of living men more often than women use electric toothbrushes, mouthwash and fluoride toothpaste. Patients with higher education utilize various advanced dental products.
\end{abstract}

Keywords: consumer behavior, oral hygiene, patients' income, place of living

\section{Introduction}

Marketers must fully understand both the theory and reality of consumer behavior. A consumer's buying behavior is influenced by cultural, social and personal factors. ${ }^{3}$ The concept of the buying behavior is strongly related to the con-

\footnotetext{
${ }^{1}$ leszek.gracz@wzieu.pl.

2 jolanta.swiderska@o2.pl.

${ }^{3}$ Ph. Kotler, K. Keller, Marketing management, Prentice Hall, Upper Saddle River, New Jersey 2006, p.174.
} 
cept of the health behavior. Health behaviors are all intentional activities performed with purpose of sustaining and improving health status. ${ }^{4}$ Health behavior is an ongoing process started in early years of our life. This process has many similarities and relations to buying behavior, for example it is influenced by different role models, most often acquired from parents but also from playgroup, school, local or religious community and media. ${ }^{5}$ For instance knowledge about dental caries is provided to children during early school years and is being developed throughout the life.

The main factors influencing hygiene of oral cavity are the frequency of tooth brushing and use of proper hygiene products, such as different types of toothpastes or mouthwashes. One's habits and lifestyle can also impact on the state of the oral cavity. Therefore maintenance of oral cavity should be performed after every meal.

Dental caries is classified as a social disease. The prevalence and possible health consequences of untreated caries are significant. ${ }^{6}$ Caries occurs mostly because of improper oral hygiene. Infrequent tooth brushing or flossing causes the plaque to appear and remain on the surface of the teeth, which increases the risk of caries development. The occurrence of caries and periodontal diseases also largely depends on nutritional behaviors. By undertaking regularly simple preventive procedures, we help not only to sustain oral cavity health but also health of the entire body.

Untreated caries may cause various organ infections and dysfunctions. Teeth with caries often cause pain, which decreases overall body mood. Despite those consequences, significant part of Polish society still indicates improper dental habits and health attitude towards prevention of caries. Prevention is a simpler method of fighting oral diseases than treatment, and is also less expensive and time consuming.

Oral cavity health requires complex approach to be effective. It's necessary to put emphasis on health education, preventive care and management of the health care. ${ }^{7}$

\footnotetext{
${ }^{4}$ A. Ostrowska, Styl życia a zdrowie, IFiS PAN, Warszawa 1999, p. 13.

${ }^{5}$ J. Piwoński, A. Pytlak, Zachowania zdrowotne i poziom wiedzy na temat wybranych zagadnień profilaktyki chorób serca młodzieży warszawskich szkót gimnazjalnych prawobrzeżnej Warszawy, "Polski Przegląd Kardiologiczny" 2003, Vol. 5, Iss. 3, p. 301-308.

${ }^{6}$ U. Kaczmarek, Czy próchnicy można skutecznie zapobiegać? Część I. Etiopatogeneza próchnicy, "Polska Medycyna Rodzinna" 2002, Vol. 4(1), p. 45-49.

7 J. Świderska, W. Świderski, Analysis of selected health behaviours favourable for sustaining proper hygiene of oral cavity. Lifestyle and wellness, Wyd. NeuroCentrum, Lublin 2011, p. 187-204;
} 
The objective of the paper is the analysis of two factors: income and place of living on health behaviors in Poland in a range of oral hygiene, understood mostly as the frequency of tooth brushing. It is well established in the literature that the low income may result in deterioration of oral cavity health, due to infrequent tooth brushing and infrequent dental examinations. ${ }^{8}$ What is more the increase in the prevalence of dental carries is noticed in the countries, where improvement of socio-economic status and urbanization takes place. ${ }^{9}$ These justify the choice of these two factors (income and place of living) as a subject of analysis.

\section{Methodology}

The aim of research was to determine patients' health behaviors in the range of oral hygiene regarding their income and place of living. The research was conducted in 2012-2013 on 180 randomly chosen adult patients (aged between 35 and 44 years), both genders living in the area of West Pomerania region - in a big city of Szczecin (over 100000 inhabitants), in smaller cities (under 100.000 inhabitants) and in villages. The analysis included dental examination of teeth status of adult patients, prevalence of caries and evaluation of oral hygiene and was conducted among patients undertaking private dental treatment or treatment reimbursed by the National Health Fund.

Clinical examination included non-invasive and secure diagnostic methods such as using WHO scale probe and dental mirror under the artificial light. Lamp for polymerization of the fillings was also used to evaluate the cavities on teeth contact surfaces.

The study was based on an anonymous survey, including single and multiple choices close-ended and open-ended questions. Results of the survey allowed evaluating patients' behaviors helping in oral disease prophylaxis and also determining socio-economic conditionings of dental health care.

Following WHO recommendation, the research determined most important socio-economic determinants of chosen groups of patients and also evaluated so-

\footnotetext{
J. Trykowski, A. Skrzypkowski, Zapobieganie chorobom jamy ustnej, "Stomatologia Współczesna" 2004, No. 2, Suplement, p. 49.

${ }^{8}$ J. Aleksejuniene, D. Holst, H.M. Eriksen, Patterns of dental caries and treatment experience in elderly Lithuanias, "Gerodontology" 2000, Vol. 17, Iss. 2, pp.77-86; J. Świderska, Healthy behaviours in sustaining oral cavity hygiene. Health and wellness, Wyd. NeuroCentrum, Lublin 2013 , p. 181-191.

${ }^{9}$ J. Grytten, D. Holst, Do young adults demand more dental services as their income increases?, “Community Dent Oral Epidemiol” 2002, Vol. 30, Iss. 6, p. 463-469.
} 
cio-demographic characteristics such as: gender and place of living. Socio-economic status and education - factors acknowledged as one of the socio-medical indicators of health - were subject of the research.

All statistical calculations were performed with use of statistical software Statistica ver. 10.0 by StatSoft Inc. (2011) and Excel calculation sheet. Quantitative variables were determined by arithmetical mean, standard deviation, median, minimum and maximum (range) and 95\% CI (confidence interval). Qualitative variables were determined by number and percentage. Significance of differences between two groups (independent variables model) was tested with significance test: t-Student or Mann-Whitney U test. Difference significance between more than two groups was tested with F (ANOVA) or Kruskal-Wallis test. Independence chi-square test was used for qualitative variables. To determine the relationship, strength and direction between variables Pearson's and/or Spearman's correlation coefficients were calculated. The level of significance $p=0.05$ was chosen for conducted study.

\section{Research results - income and place of living of surveyed patients}

The study involved 180 patients, 90 women and 90 men, who underwent dental examination determining their teeth and oral hygiene status. Study was conducted in a big city, smaller cities and villages. Each examined person completed a questionnaire on utilization of dental services, oral hygiene and access to dental services.

The first part of the research concerned the income and place of living of surveyed patients. The table 1 presents the gender of surveyed patients. Patients were divided into two equal gender groups - 90 women and 90 men.

Table 1

Gender of surveyed patients

\begin{tabular}{|l|c|c|}
\hline \multicolumn{1}{|c|}{ Gender } & N & $\%$ \\
\hline Women & 90 & 50.0 \\
\hline Men & 90 & 50.0 \\
\hline Sum & 180 & 100.0 \\
\hline
\end{tabular}

Source: own research

The place of living was aggregated into three main categories: big city, smaller cities and villages. The place of living of surveyed patients, with the regard to their gender is presented in table 2. The study involved 90 women and 90 men, which were divided into groups related to their place of living. Each group consists of 30 women and 30 men from a big city, smaller cities and villages. 
Place of living and gender of surveyed patients

\begin{tabular}{|l|c|c|c|c|}
\hline \multirow{2}{*}{ Place of living } & \multicolumn{2}{|c|}{ Women } & \multicolumn{2}{c|}{ Men } \\
\cline { 2 - 5 } & $\mathrm{N}$ & $\%$ & $\mathrm{~N}$ & $\%$ \\
\hline Big city & 30 & 33.3 & 30 & 33.3 \\
\hline Smaller cities & 30 & 33.3 & 30 & 33.3 \\
\hline Villages & 30 & 33.3 & 30 & 33.3 \\
\hline Sum & 90 & 100.0 & 90 & 100.0 \\
\hline
\end{tabular}

Source: own research.

The second factor analyzed in the research was patients' income. The table 3 presents the income per person in a household of surveyed patients with regard to their gender. Women and men most often indicated income of more than 1200 PLN per person in a household (respectively 29 and 54 patients).

Table 3

Income per person in a household and gender of surveyed patients

\begin{tabular}{|l|c|c|c|c|}
\hline \multirow{2}{*}{\multicolumn{1}{|c|}{ Income }} & \multicolumn{2}{c|}{ Women } & \multicolumn{2}{c|}{ Men } \\
\cline { 2 - 5 } & $\mathrm{N}$ & $\%$ & $\mathrm{~N}$ & $\%$ \\
\hline Up to 300 PLN & 3 & 3.3 & 0 & 0.0 \\
\hline 301-500 PLN & 12 & 13.3 & 4 & 4.4 \\
\hline 501-800 PLN & 24 & 26.7 & 14 & 15.6 \\
\hline 801-1200 PLN & 22 & 24.4 & 18 & 20.0 \\
\hline More than 1200 PLN & 29 & 32.2 & 54 & 60.0 \\
\hline Sum & 90 & 100.0 & 90 & 100.0 \\
\hline
\end{tabular}

Source: own research.

Next, the cross analysis of income and place of living was performed. The results are presented in table 4 .

Table 4

Income per person in a household and place of living of surveyed patients

\begin{tabular}{|l|c|c|c|c|c|c|}
\hline \multirow{2}{*}{\multicolumn{1}{|c|}{ Income }} & \multicolumn{2}{|c|}{ Big city } & \multicolumn{2}{c|}{ Smaller cities } & \multicolumn{2}{c|}{ Villages } \\
\cline { 2 - 7 } & $\mathrm{N}$ & $\%$ & $\mathrm{~N}$ & $\%$ & $\mathrm{~N}$ & $\%$ \\
\hline Up to 300 PLN & 3 & 5.0 & 0 & 0.0 & 0 & 0.0 \\
\hline $301-500$ PLN & 6 & 10.0 & 1 & 1.7 & 9 & 15.0 \\
\hline $501-800$ PLN & 10 & 16.7 & 13 & 21.7 & 15 & 25.0 \\
\hline 801-1200 PLN & 14 & 23.3 & 16 & 26.7 & 10 & 16.6 \\
\hline More than 1200 PLN & 27 & 45.0 & 30 & 50.0 & 26 & 43.3 \\
\hline Sum & 60 & 100.0 & 60 & 100.0 & 60 & 100.0 \\
\hline
\end{tabular}

Source: own research 
Surveyed patients most often indicated income of more than 1200 PLN per person in a household. Income of 801-1200 PLN was indicated by 40 patients and income of 501-800 PLN was indicated by 38 patients. Among surveyed patients 16 have indicated income of 301-500 PLN and 3 people have indicated income of up to 300 PLN per person in a household.

\section{Research results - health behaviors in a range of oral hygiene}

The second part of the research concerned the health behaviors in a range of oral hygiene. Table 5 presents the frequency of teeth brushing. Majority of surveyed patients brush their teeth twice a day (64.8\%).

Table 5

Frequency of brushing teeth

\begin{tabular}{|l|c|c|}
\hline How often do you brush your teeth? & $\mathrm{N}$ & $\%$ \\
\hline After every meal & 30 & 16.8 \\
\hline Twice a day & 116 & 64.8 \\
\hline Once a day & 30 & 16.8 \\
\hline Less often than once a day & 1 & 0.6 \\
\hline Sporadically & 2 & 1.1 \\
\hline Sum & 179 & 100 \\
\hline
\end{tabular}

Source: own research.

There are some differences in teeth brushing among men and women, as indicated in table 6.

Table 6

Frequency of brushing teeth in relation to gender of surveyed patients

\begin{tabular}{|l|c|c|c|c|}
\hline \multirow{2}{*}{ How often do you brush your teeth? } & \multicolumn{2}{|c|}{ Women } & \multicolumn{2}{c|}{ Men } \\
\cline { 2 - 5 } & $\mathrm{N}$ & $\%$ & $\mathrm{~N}$ & $\%$ \\
\hline After every meal & 18 & 20.2 & 12 & 13.3 \\
\hline Twice a day & 59 & 66.3 & 57 & 63.3 \\
\hline Once a day & 12 & 13.5 & 18 & 20.0 \\
\hline Less often than once a day & 0 & 0.0 & 1 & 1.1 \\
\hline Sporadically & 0 & 0.0 & 2 & 2.2 \\
\hline Sum & 89 & 100.0 & 90 & 100.0 \\
\hline
\end{tabular}

Source: own research.

Majority of both women (66.3\%) and men (63.3\%) brush their teeth twice a day. Women (20.2\%) more often than men (13.3\%) brush their teeth after every meal. 


\section{Research results - the impact of income and place of living health behaviors in a range of oral hygiene}

Realizing the objective of the paper, the cross analysis of income and place of living with the frequency of tooth brushing was performed. The table 7 presents the frequency of brushing teeth in relation to place of living of surveyed patients.

Table 7

Frequency of brushing teeth in relation to place of living of surveyed patients

\begin{tabular}{|l|c|c|c|c|c|c|}
\hline \multirow{2}{*}{ How often do you brush your teeth? } & \multicolumn{2}{|c|}{ Big city } & \multicolumn{2}{c|}{ Smaller cities } & \multicolumn{2}{c|}{ Villages } \\
\cline { 2 - 7 } & $\mathrm{N}$ & $\%$ & $\mathrm{~N}$ & $\%$ & $\mathrm{~N}$ & $\%$ \\
\hline After every meal & 11 & 18.3 & 12 & 20.0 & 7 & 11.9 \\
\hline Twice a day & 39 & 65.0 & 39 & 65.0 & 38 & 64.4 \\
\hline Once a day & 9 & 15.0 & 9 & 15.0 & 12 & 20.3 \\
\hline Less often than once a day & 1 & 1.7 & 0 & 0.0 & 0 & 0.0 \\
\hline Sporadically & 0 & 0.0 & 0 & 0.0 & 2 & 3.4 \\
\hline Sum & 60 & 100.0 & 60 & 100.0 & 59 & 100.0 \\
\hline
\end{tabular}

Source: own research.

Regardless of the place of living surveyed patients most often brush their teeth twice a day ( $65 \%$ of patients from a big city and smaller cities and $64.4 \%$ of patients from villages). More than $80 \%$ of patients from a big city and smaller cities brush their teeth at least twice a day. Approximately $24 \%$ of patients from villages brush their teeth once a day or less often.

The table 8 presents the frequency of brushing teeth in relation to income per person in a household of surveyed patients.

Table 8

Frequency of brushing teeth in relation to income per person in a household of surveyed patients

\begin{tabular}{|l|c|c|c|c|c|c|c|c|c|c|}
\hline \multirow{2}{*}{$\begin{array}{c}\text { How often do you } \\
\text { brush your teeth? }\end{array}$} & \multicolumn{2}{|c|}{$\begin{array}{c}\text { Up to 300 } \\
\text { PLN }\end{array}$} & \multicolumn{2}{c|}{$\begin{array}{c}301-500 \\
\text { PLN }\end{array}$} & \multicolumn{2}{c|}{$\begin{array}{c}\text { 501-800 } \\
\text { PLN }\end{array}$} & \multicolumn{2}{c|}{$\begin{array}{c}\text { 801-1200 } \\
\text { PLN }\end{array}$} & \multicolumn{2}{c|}{$\begin{array}{c}\text { More than } \\
1200 \text { PLN }\end{array}$} \\
\cline { 2 - 13 } & $\mathrm{N}$ & $\%$ & $\mathrm{~N}$ & $\%$ & $\mathrm{~N}$ & $\%$ & $\mathrm{~N}$ & $\%$ & $\mathrm{~N}$ & $\%$ \\
\hline After every meal & 1 & 33.3 & 2 & 12.5 & 6 & 15.8 & 8 & 20.00 & 13 & 15.9 \\
\hline Twice a day & 2 & 66.7 & 8 & 50.0 & 22 & 57.9 & 26 & 65.0 & 58 & 70.7 \\
\hline Once a day & 0 & 0.0 & 5 & 31.3 & 10 & 26.3 & 6 & 15.00 & 9 & 11.0 \\
\hline $\begin{array}{l}\text { Less often than once } \\
\text { a day }\end{array}$ & 0 & 0.0 & 0 & 0.0 & 0 & 0.0 & 0 & 0.0 & 1 & 1.2 \\
\hline Sporadically & 0 & 0.0 & 1 & 6.3 & 0 & 0.0 & 0 & 0.0 & 1 & 1.2 \\
\hline Sum & 3 & 100.0 & 16 & 100.0 & 38 & 100.0 & 40 & 100.0 & 82 & 100.0 \\
\hline
\end{tabular}

Source: own research. 
Regardless of income surveyed patients most often brush their teeth twice a day. Among patients with income of 301-500 PLN, 31.3\% of patients brush their teeth once a day and $6.3 \%$ brush their teeth sporadically.

There are also some differences in a range of oral hygiene depending on the gender of surveyed patients. The table 9 presents the frequency of brushing teeth in relation to place of living and gender of surveyed patients.

Table 9

Frequency of brushing teeth in relation to place of living and gender of surveyed patients

\begin{tabular}{|l|c|c|c|c|c|c|c|c|c|c|c|c|}
\hline \multirow{2}{*}{$\begin{array}{l}\text { How often do you } \\
\text { brush your teeth? }\end{array}$} & \multicolumn{4}{|c|}{ Big city } & \multicolumn{4}{c|}{ Smaller cities } & \multicolumn{4}{c|}{ Villages } \\
\cline { 2 - 16 } & \multicolumn{2}{|c|}{ Women } & \multicolumn{2}{|c|}{ Men } & \multicolumn{2}{c|}{ Women } & \multicolumn{2}{c|}{ Men } & \multicolumn{2}{c|}{ Women } & \multicolumn{2}{c|}{ Men } \\
\cline { 2 - 15 } & $\mathrm{N}$ & $\%$ & $\mathrm{~N}$ & $\%$ & $\mathrm{~N}$ & $\%$ & $\mathrm{~N}$ & $\%$ & $\mathrm{~N}$ & $\%$ & $\mathrm{~N}$ & $\%$ \\
\hline After every meal & 4 & 13.3 & 7 & 23.3 & 9 & 30.0 & 3 & 10.0 & 5 & 17.2 & 2 & 6.7 \\
\hline Twice a day & 25 & 83.3 & 14 & 46.7 & 15 & 50.0 & 24 & 80.0 & 19 & 65.5 & 19 & 63.3 \\
\hline Once a day & 1 & 3.3 & 8 & 26.7 & 6 & 20.0 & 3 & 10.0 & 5 & 17.2 & 7 & 23.3 \\
\hline $\begin{array}{l}\text { Less often than } \\
\text { once a day }\end{array}$ & 0 & 0.0 & 1 & 3.3 & 0 & 0.0 & 0 & 0.0 & 0 & 0.0 & 0 & 0.0 \\
\hline Sporadically & 0 & 0.0 & 0 & 0.0 & 0 & 0.0 & 0 & 0.0 & 0 & 0.0 & 2 & 6.7 \\
\hline Sum & 30 & 100.0 & 30 & 100.0 & 30 & 100.0 & 30 & 100.0 & 29 & 100.0 & 30 & 100.0 \\
\hline
\end{tabular}

Source: own research.

Regardless of gender and place of living surveyed patients most often brush their teeth twice a day. Women from a big city more often than women from smaller cities and villages brush their teeth twice a day or after each meal (respectively approximately $97 \%, 80 \%$ and $83 \%$ ). Women from smaller cities and villages more often brush their teeth after every meal than men from smaller cities and villages (from smaller cities: women $30 \%$, men $10 \%$ and from villages: women $17.2 \%$, men $6.7 \%$ ).

There are also some interesting insights from the analysis of the impact of both the place of living and the income on teeth brushing. The table 10 presents the frequency of brushing teeth in relation to income per person in a household of surveyed patients from a big city, followed by table 11 presenting this frequency for smaller cities, and table 12 for villages. Regardless of income surveyed patients from a big city most often brush their teeth twice a day. Patients with income of up to 300 PLN and 801-1200 PLN most often of all patients brush their teeth after every meal (respectively $33.3 \%$ and $28.6 \%$ ). The table 10 presents the frequency of brushing teeth in relation to income per person in a household of surveyed patients from smaller cities. Regardless of income surveyed patients from smaller cities most often brush their teeth twice a day. The table 12 presents the frequency of brushing teeth in relation to income per person in a household of surveyed patients from villages. 
Table 10

Frequency of brushing teeth in relation to income per person in a household of surveyed patients from a big city

\begin{tabular}{|l|c|c|c|c|c|c|c|c|c|c|}
\hline \multirow{3}{*}{$\begin{array}{c}\text { How often do you brush } \\
\text { your teeth? }\end{array}$} & \multicolumn{8}{|c|}{ Income of patients from a big city } \\
\cline { 2 - 13 } & $\begin{array}{c}\text { Up to 300 } \\
\text { PLN }\end{array}$ & \multicolumn{2}{c|}{$\begin{array}{c}301-500 \\
\text { PLN }\end{array}$} & \multicolumn{2}{c|}{$\begin{array}{c}501-800 \\
\text { PLN }\end{array}$} & \multicolumn{2}{c|}{$\begin{array}{c}801-1200 \\
\text { PLN }\end{array}$} & \multicolumn{2}{c|}{$\begin{array}{c}\text { More than } \\
1200 \text { PLN }\end{array}$} \\
\cline { 2 - 12 } & $\mathrm{N}$ & $\%$ & $\mathrm{~N}$ & $\%$ & $\mathrm{~N}$ & $\%$ & $\mathrm{~N}$ & $\%$ & $\mathrm{~N}$ & $\%$ \\
\hline After every meal & 1 & 33.3 & 0 & 0.0 & 2 & 20.0 & 4 & 28.6 & 4 & 14.8 \\
\hline Twice a day & 2 & 66.7 & 5 & 83.3 & 7 & 70.0 & 8 & 57.1 & 17 & 63.0 \\
\hline Once a day & 0 & 0.0 & 1 & 16.7 & 1 & 10.0 & 2 & 14.3 & 5 & 18.5 \\
\hline Less often than once a day & 0 & 0.0 & 0 & 0.0 & 0 & 0.0 & 0 & 0.0 & 1 & 3.7 \\
\hline Sporadically & 0 & 0.0 & 0 & 0.0 & 0 & 0.0 & 0 & 0.0 & 0 & 0.0 \\
\hline Sum & 3 & 100.0 & 6 & 100.0 & 10 & 100.0 & 14 & 100.0 & 27 & 100.0 \\
\hline
\end{tabular}

Source: own research.

Table 11

Frequency of brushing teeth in relation to income per person in a household of surveyed patients from smaller cities

\begin{tabular}{|l|c|c|c|c|c|c|c|c|c|c|}
\hline \multirow{3}{*}{$\begin{array}{c}\text { How often do you brush } \\
\text { your teeth? }\end{array}$} & \multicolumn{8}{|c|}{ Income of patients from smaller cities } \\
\cline { 2 - 13 } & $\begin{array}{c}\text { Up to 300 } \\
\text { PLN }\end{array}$ & \multicolumn{2}{|c|}{$\begin{array}{c}\text { 301-500 } \\
\text { PLN }\end{array}$} & \multicolumn{2}{c|}{$\begin{array}{c}501-800 \\
\text { PLN }\end{array}$} & \multicolumn{2}{c|}{$\begin{array}{c}801-1200 \\
\text { PLN }\end{array}$} & \multicolumn{2}{c|}{$\begin{array}{c}\text { More than } \\
1200 \text { PLN }\end{array}$} \\
\cline { 2 - 13 } & $\mathrm{N}$ & $\%$ & $\mathrm{~N}$ & $\%$ & $\mathrm{~N}$ & $\%$ & $\mathrm{~N}$ & $\%$ & $\mathrm{~N}$ & $\%$ \\
\hline After every meal & 0 & - & 0 & 0.0 & 0 & 0.0 & 4 & 25.0 & 8 & 26.7 \\
\hline Twice a day & 0 & - & 0 & 0.0 & 7 & 53.8 & 11 & 68.8 & 21 & 70.0 \\
\hline Once a day & 0 & - & 1 & 100.0 & 6 & 46.2 & 1 & 6.3 & 1 & 3.3 \\
\hline Less often than once a day & 0 & - & 0 & 0.0 & 0 & 0.0 & 0 & 0.0 & 0 & 0.0 \\
\hline Sporadically & 0 & - & 0 & 0.0 & 0 & 0.0 & 0 & 0.0 & 0 & 0.0 \\
\hline Sum & 0 & - & 1 & 100.0 & 13 & 100.0 & 16 & 100.0 & 30 & 100.0 \\
\hline
\end{tabular}

Source: own research.

Table 12

Frequency of brushing teeth in relation to income per person in a household of surveyed patients from villages

\begin{tabular}{|l|c|c|c|c|c|c|c|c|c|c|}
\hline \multirow{3}{*}{$\begin{array}{c}\text { How often do you brush } \\
\text { your teeth? }\end{array}$} & \multicolumn{8}{|c|}{ Income of patients from villages } \\
\cline { 2 - 13 } & $\begin{array}{c}\text { Up to 300 } \\
\text { PLN }\end{array}$ & \multicolumn{2}{|c|}{$\begin{array}{c}\text { PL1-500 } \\
\text { PLN }\end{array}$} & \multicolumn{2}{c|}{$\begin{array}{c}501-800 \\
\text { PLN }\end{array}$} & \multicolumn{2}{c|}{$\begin{array}{c}801-1200 \\
\text { PLN }\end{array}$} & $\begin{array}{c}\text { More than } \\
1200 \text { PLN }\end{array}$ \\
\cline { 2 - 13 } & $\mathrm{N}$ & $\%$ & $\mathrm{~N}$ & $\%$ & $\mathrm{~N}$ & $\%$ & $\mathrm{~N}$ & $\%$ & $\mathrm{~N}$ & $\%$ \\
\hline After every meal & 0 & - & 2 & 22.2 & 4 & 26.7 & 0 & 0.0 & 1 & 4.0 \\
\hline Twice a day & 0 & - & 3 & 33.3 & 8 & 53.3 & 7 & 70.0 & 20 & 80.0 \\
\hline Once a day & 0 & - & 3 & 33.3 & 3 & 20.0 & 3 & 30.0 & 3 & 12.0 \\
\hline Less often than once a day & 0 & - & 0 & 0.0 & 0 & 0.0 & 0 & 0.0 & 0 & 0.0 \\
\hline Sporadically & 0 & - & 1 & 11.1 & 0 & 0.0 & 0 & 0.0 & 1 & 4.0 \\
\hline Sum & 0 & - & 9 & 100.0 & 15 & 100.0 & 10 & 100.0 & 25 & 100.0 \\
\hline
\end{tabular}

Source: own research. 
Patients from villages with income of more than 1200 PLN most often of all patients brush their teeth twice a day (80.0\%). Patients with income 501-800 PLN most often of all patients brush their teeth after every meal (26.7\%).

The other aspect of oral hygiene is using various oral hygiene products, such as electric toothbrush, interdental toothbrush, dental floss, toothpicks, fluoride toothpaste, specific type toothpaste or mouthwash. The usage of these products with relation to the place of living is presented in table 13, and the usage of these products with relation to the income is presented in table 14 .

Table 13

Use of dental hygiene products in relation to place of living and gender of surveyed patients

\begin{tabular}{|c|c|c|c|c|c|c|c|c|c|c|c|c|}
\hline \multirow{3}{*}{$\begin{array}{l}\text { What oral hygiene } \\
\text { products do you use? }\end{array}$} & \multicolumn{4}{|c|}{ Big city } & \multicolumn{4}{|c|}{ Smaller cities } & \multicolumn{4}{|c|}{ Villages } \\
\hline & \multicolumn{2}{|c|}{ Women } & \multicolumn{2}{|c|}{ Men } & \multicolumn{2}{|c|}{ Women } & \multicolumn{2}{|c|}{ Men } & \multicolumn{2}{|c|}{ Women } & \multicolumn{2}{|c|}{ Men } \\
\hline & $\mathrm{N}$ & $\%$ & $\mathrm{~N}$ & $\%$ & $\mathrm{~N}$ & $\%$ & $\mathrm{~N}$ & $\%$ & $\mathrm{~N}$ & $\%$ & $\mathrm{~N}$ & $\%$ \\
\hline Traditional toothbrush & 25 & 83.3 & 24 & 80.0 & 27 & 90.0 & 26 & 86.7 & 26 & 86.7 & 28 & 93.3 \\
\hline Electric toothbrush & 3 & 10.0 & 8 & 26.7 & 3 & 10.0 & 7 & 23.3 & 3 & 10.0 & 2 & 6.7 \\
\hline Interdental toothbrush & 0 & 0.0 & 1 & 3.3 & 5 & 16.7 & 0 & 0.0 & 0 & 0.0 & 0 & 0.0 \\
\hline Dental floss & 15 & 50.0 & 15 & 50.0 & 15 & 50.0 & 9 & 30.0 & 11 & 36.7 & 7 & 23.3 \\
\hline Toothpicks & 4 & 13.3 & 5 & 16.7 & 9 & 30.0 & 11 & 36.7 & 5 & 16.7 & 9 & 30.0 \\
\hline Fluoride toothpaste & 10 & 33.3 & 17 & 56.7 & 19 & 63.3 & 24 & 80.0 & 15 & 50.0 & 16 & 53.3 \\
\hline Specific type toothpaste & 17 & 56.7 & 8 & 26.7 & 15 & 50.0 & 7 & 23.3 & 11 & 36.7 & 6 & 20.0 \\
\hline Mouthwash & 17 & 56.7 & 20 & 66.7 & 14 & 46.7 & 20 & 66.7 & 11 & 36.7 & 12 & 40.0 \\
\hline $\begin{array}{l}\text { Number of people in } \\
\text { a group }\end{array}$ & 30 & - & 30 & - & 30 & - & 30 & - & 30 & & 30 & - \\
\hline
\end{tabular}

*surveyed patients were able to select many answers, values do not sum up to $100 \%$

Source: own research.

Women from a big city (83.3\%) and smaller cities (90.0\%) more often than men (respectively $80.0 \%$ and $86.7 \%$ ) use traditional toothbrush. Men regardless of their place of living more often than women use electric toothbrush, mouthwash and fluoride toothpaste.

The table 14 presents the usage of dental hygiene products in relation to income per person in a household of surveyed patients.

Table 14

Use of dental hygiene products in relation to income per person in a household of surveyed patients

\begin{tabular}{|c|c|c|c|c|c|c|c|c|c|c|}
\hline \multirow{2}{*}{$\begin{array}{l}\text { What oral hygiene } \\
\text { products do you use? }\end{array}$} & \multicolumn{2}{|c|}{$\begin{array}{l}\text { Up to } 300 \\
\text { PLN }\end{array}$} & \multicolumn{2}{|c|}{$\begin{array}{c}301-501 \\
\text { PLN }\end{array}$} & \multicolumn{2}{|c|}{$\begin{array}{c}501-800 \\
\text { PLN }\end{array}$} & \multicolumn{2}{|c|}{$\begin{array}{l}801-1200 \\
\text { PLN }\end{array}$} & \multicolumn{2}{|c|}{$\begin{array}{l}\text { More than } \\
1200 \text { PLN }\end{array}$} \\
\hline & $\mathrm{N}$ & $\%$ & $\mathrm{~N}$ & $\%$ & $\mathrm{~N}$ & $\%$ & $\mathrm{~N}$ & $\%$ & $\mathrm{~N}$ & $\%$ \\
\hline Traditional toothbrush & 2 & 66.7 & 16 & 100.0 & 38 & 100.0 & 35 & 87.5 & 65 & 78.3 \\
\hline Electric toothbrush & 0 & 0.0 & 0 & 0.0 & 0 & 0.0 & 3 & 7.5 & 23 & 27.7 \\
\hline Interdental toothbrush & 0 & 0.0 & 0 & 0.0 & 0 & 0.0 & 4 & 10.0 & 2 & 2.4 \\
\hline Dental floss & 0 & 0.0 & 2 & 12.5 & 14 & 36.8 & 17 & 42.5 & 39 & 47.0 \\
\hline
\end{tabular}




\begin{tabular}{|l|c|c|c|c|c|c|c|c|c|c|}
\hline Toothpicks & 1 & 33.3 & 3 & 18.8 & 8 & 21.1 & 11 & 27.5 & 20 & 24.1 \\
\hline Fluoride toothpaste & 0 & 0.0 & 10 & 62.5 & 24 & 63.2 & 19 & 47.5 & 48 & 57.8 \\
\hline Specific type toothpaste & 3 & 100.0 & 5 & 31.3 & 8 & 21.1 & 17 & 42.5 & 31 & 37.4 \\
\hline Mouthwash & 2 & 66.7 & 3 & 18.8 & 15 & 39.5 & 22 & 55.0 & 52 & 62.7 \\
\hline $\begin{array}{l}\text { Number of people } \\
\text { in a group }\end{array}$ & 3 & - & 16 & - & 38 & - & 40 & & 83 & - \\
\hline
\end{tabular}

Source: own research/

Patients with income of 801-1200 PLN and more than 1200 PLN most often used various dental hygiene products, such as electric toothbrush, specific type toothpaste, mouthwash or dental floss.

\section{Discussion of the results}

Health behaviors are defined as all intentional activities performed by a person, which purpose is to sustain or increase health potential. ${ }^{10}$ According to Piwoński and Pytlak health behaviour is developed already in the earliest years of life. This process occurs under the influence of different role models taken from home, playgroup, school, local or religious community, and media. ${ }^{11}$ The intensity of dental carries is definitely higher in developing countries, to which Poland is classified, than in highly developed countries. ${ }^{12}$

Klichowska-Palonka et al. obtained the results which showed that most respondents $-46.5 \%$ - brush teeth twice a day, $41.4 \%$ - once a day and $12.1 \%$ after every meal ${ }^{13}$. In the study conducted by Bałczewska $18.2 \%$ of surveyed patients brushed their teeth 3 times a day, $60.9 \%$ - twice a day, $10.9 \%$ - once a day and only $2.2 \%$ of respondents do not brush their teeth at all. ${ }^{14}$

The results obtained in research are similar $-16.8 \%$ of patients brush their teeth after every meal, $64.8 \%$ brush their teeth twice a day, $16.8 \%$ brush teeth once a day and $1.7 \%$ of surveyed patients brush their teeth less often than once a day. Differentiation between socio-economic status of cities and villages inhabitants have significant influence on health behaviours in range of oral cavity hygiene. ${ }^{15}$

\footnotetext{
${ }^{10}$ A. Ostrowska, Styl życia a zdrowie..., p. 13.

${ }^{11}$ J. Piwoński, A. Pytlak, Zachowania zdrowotne ..., p. 301-308.

${ }^{12}$ D. Ilczuk et al., Ocena porównawcza stanu uzębienia i stomatologicznych zachowań zdrowotnych uczniów szkót ponadgimnazjalnych, "Stomatologia Współczesna" 2005, Vol. 12, No. 5, p. 14-19.

${ }^{13} \mathrm{M}$. Klichowska-Palonka et al., Badania ankietowe z zakresu higieny jamy ustnej grupy ludności wiejskiej, "Magazyn Stomatologiczny" 1997, No. 7, p. 10-14.

${ }^{14}$ E. Bałczewska, Zachowania zdrowotne dorostych pacjentów przychodni periodontologicznej. Badania ankietowe, "Czasopismo Stomatologiczne" 1993, Vol. 46, No. 11/12, p. 744-747.

${ }^{15}$ F. Szatko, Społeczne uwarunkowania stanu zdrowotnego jamy ustnej, Akademia Medyczna w Łodzi, Łódź 2001, p. 123, 140-158, 221.
} 
Carried out research shows that regardless of place of living, majority of patients brush their teeth twice a day. Patients from villages less often than patients from smaller cities and big city brush their teeth after every meal.

In her studies Bałczewska proved that the primary utensil used to sustain health of the oral cavity was a traditional toothbrush ( $94.8 \%$ of answers) and toothpaste $-81.8 \%$ of answers. Other questionnaires mentioned: using mouthwash $-26.1 \%$ of answers, toothpicks $-14,6 \%$ of answers, $13.9 \%$ - dental floss and $4.6 \%$ used complete hygiene kits. ${ }^{16}$

Women from a big city $(83.3 \%)$ and smaller cities $(90.0 \%)$ more often than men (respectively $80.0 \%$ and $86.7 \%$ ) use traditional toothbrush. Men more often than women use electric toothbrush, mouthwash and fluoride toothpaste.

\section{Conclusions}

Following conclusions were drawn from the study:

1. The vast majority of surveyed patients brush their teeth twice a day.

2. Women more often than men brush their teeth twice a day or after every meal. Only among men there are patients who brush their teeth less often than once a day.

3. Regardless of the place of living and income surveyed patients most often brush their teeth twice a day.

4. Patients from villages less often than other patients brush their teeth twice a day or after every meal.

5. The higher the income of patients the more advanced hygiene products they use.

\section{Bibliography}

Aleksejuniene J., Holst D., Eriksen H.M., Patterns of dental caries and treatment experience in elderly Lithuanias, "Gerodontology" 2000, Vol. 17, Iss. 2.

Bałczewska E., Zachowania zdrowotne dorostych pacjentów przychodni periodontologicznej. Badania ankietowe, "Czasopismo Stomatologiczne" 1993, Vol. 46, No. 11/12.

Grytten J., Holst D., Do young adults demand more dental services as their income increases? "Community Dent Oral Epidemiol" 2002, Vol. 30, Iss. 6.

Ilczuk D. et al., Ocena porównawcza stanu uzębienia i stomatologicznych zachowań zdrowotnych uczniów szkół ponadgimnazjalnych, "Stomatologia Współczesna" 2005, Vol. 12, No. 5.

Kaczmarek U., Czy próchnicy można skutecznie zapobiegać? Część I. Etiopatogeneza próchnicy, "Polska Medycyna Rodzinna" 2002, Vol 4(1).

${ }^{16}$ E. Bałczewska: Zachowania zdrowotne ..., pp. 744-747. 
Klichowska-Palonka M. et al., Badania ankietowe z zakresu higieny jamy ustnej grupy ludności wiejskiej, "Magazyn Stomatologiczny” 1997, No. 7.

Kotler Ph., Keller K., Marketing management, Prentice Hall, Upper Saddle River, New Jersey 2006.

Ostrowska A., Styl życia a zdrowie, IFiS PAN, Warszawa 1999.

Piwoński J., Pytlak A., Zachowania zdrowotne i poziom wiedzy na temat wybranych zagadnień profilaktyki chorób serca młodzieży warszawskich szkół gimnazjalnych prawobrzeżnej Warszawy, "Polski Przegląd Kardiologiczny" 2003, Vol. 5, Iss. 3.

Szatko F., Społeczne uwarunkowania stanu zdrowotnego jamy ustnej, Akademia Medyczna w Łodzi, Łódź 2001.

Świderska J., Healthy behaviours in sustaining oral cavity hygiene. Health and wellness, Wyd. NeuroCentrum, Lublin 2013.

Świderska J., Świderski W., Analysis of selected health behaviours favourable for sustaining proper hygiene of oral cavity. Lifestyle and wellness, Wyd. NeuroCentrum, Lublin 2011.

Trykowski J., Skrzypkowski A., Zapobieganie chorobom jamy ustnej, "Stomatologia Współczesna” 2004, No. 2 Suplement.

\section{WPLYW DOCHODU I MIEJSCA ZAMIESZKANIA NA ZACHOWA- NIA ZDROWOTNE W ZAKRESIE UTRZYMANIA WŁAŚCIWEJ HIGIENY JAMY USTNEJ NA PODSTAWIE BADANIA PACJENTÓW}

\section{Streszczenie}

Celem artykułu było zbadanie zachowań pacjentów w zakresie utrzymania higieny jamy ustnej z uwzględnieniem ich dochodu i środowiska zamieszkania. Grupę badawczą stanowiło 180 pacjentów, 90 kobiet i 90 mężczyzn w wieku 35-44 lata z dużego miasta, małych miejscowości i wsi województwa zachodniopomorskiego. Przeprowadzono lekarskie badanie stomatologiczne, które pozwoliło określić stan zdrowia jamy ustnej pacjentów, oraz badanie ankietowe dotyczące między innymi korzystania przez pacjentów ze świadczeń stomatologicznych, higieny jamy ustnej, dostępu do opieki stomatologicznej. Zdecydowana większość kobiet i mężczyzn myje zęby dwa razy dziennie, jednak kobiety częściej niż mężczyźni myją zęby po każdym posiłku. Niezależnie od miejsca zamieszkania mężczyźni częściej niż kobiety używają szczoteczek elektrycznych, płynu do płukania jamy ustnej i pasty z fluorem. Pacjenci z wyższym dochodem korzystają z różnorodnych specjalistycznych produktów higienicznych.

Słowa kluczowe: zachowanie nabywców, higiena jamy ustnej, dochód pacjentów, miejsce zamieszkania 
